\title{
AMERICAN COMMERCIAL INTERESTS IN MANCHURIA
}

\author{
By Dana G. Munro, \\ University of Wisconsin.
}

The three Eastern Provinces of the Chinese Empire, collectively known as Manchuria, have a combined area of about 363,6 Iо square miles, and a population variously estimated at from fifteen to twenty-five millions. ${ }^{1}$ They are remarkably rich, both in agricultural products and in minerals. The soil, with the aid of an abundant and fairly uniform rainfall, produces heavy crops of beans and grain year after year, without showing signs of depletion; while underground there are immense deposits, as yet unexploited, of gold, silver, copper, lead, and coal. The population consists largely of immigrants, who are coming to Manchuria in great numbers from the less fertile provinces of the empire. ${ }^{2}$ These are more progressive and less opposed to foreigners than the people of many other parts of China; and because of this fact, and also because of the greater per capita wealth due to the richness of the land, Manchuria offers an unusually favorable market for foreign products. In the year I9IO, although the provinces were just beginning to recover from the destructive war recently fought within their limits, the total volume of their trade amounted to $\$ 110,000,000$.

This great commercial activity is partly due to the fact that there is no other part of the Chinese Empire so accessible to foreign enterprise. Most of the important cities have been opened to foreign trade, and an extensive railway system, combined with four large navigable rivers, ${ }^{3}$ has afforded transportation such as is unknown in the other provinces. Until 1898, Newchwang, opened to trade in 1864, was the only port of entry for foreign

1 The names of the provinces, together with the estimated population of each, as given in the Statesman's Year Book for 1911, are: Shenking, 10,312,241; Kirin, 6,000,000; and Hellung.Chiang, 1,500,000.

${ }^{2}$ A recent report from the United States Consul at Harbin states that a government committee, in a two weeks' session at Harbin, sold 40,000 small farms In Hellung-Chiang Province to immigrants, at a total cost to the purchaser of 82.22 per acre.

3 The Amur, the Sungarl, the Yalu, and the Liao. 
commerce in Manchuria, although a certain amount of foreign goods came into the country over the Trans-Siberian Railroad in the North. From Newchwang, merchandise was sent into the interior by means of junks on the Liao River, or overland by cart. In I898, Russia opened the port of Dalny, within her leased territory of Liaotung, but in spite of constant efforts to divert trade to the new port, Newchwang still retained its commercial leadership. In I9OI, the Chinese Eastern Railway, built by Russia, was opened to traffic, connecting these two ports in the South with the Trans-Siberian system and with the cities of the interior. The Treaty of Portsmouth gave the southern section of this line, now called the Southern Manchurian Railway, to the Japanese, who rebuilt it and replaced the old Russian wide gauge by standard gauge, thus making it necessary to transship freight at Changchun, the point of division. Since the war, also, a great number of new ports have been opened, and Japan has built a railroad connecting Mukden, on the Southern Manchurian line, with Antung and the Korean Railway. China herself is building a railroad from Changchun to Kirin, which will draw traffic from a large section at present inaccessible."

In spite of these improvements in commercial facilities, trade in this section of China is by no means free from certain disadvantages which have hampered business elsewhere in the empire. The most serious of these is the appalling chaos of the currency system. This cannot be described here, but the state of affairs can be imagined from the statement that there are generally at least a dozen forms of money circulating at each port, and that these vary considerably from month to month in their rate of exchange, not only in regard to gold, but also in regard to each other. Such a condition adds a gambling element to the most conservative business. Recently, on account of pressure from the United States and other powers, steps have been taken towards the adoption of a uniform currency throughout the empire, and a substantial improvement is looked for in the next few years. Another hindrance to trade is the tariff system. Likin, or transportation, dues are levied on merchandise at every point where it is possible to establish a barrier, and the resulting expense and annoy-

- According to the Daily Consular Reports for Nov. 18, 1911, the AntungMukden line was to have been open to traffic about Nov. 3, 1911, and the ChangchunKIrIn line by the end of 1912. 
ance burden commerce considerably. The payment of a $2^{\mathrm{T}} / 2$ per cent ad valorem surtax at the maritime customs house is supposed legally to free foreign goods from these dues, but the transit passes secured in this way are often not respected in the interior. ${ }^{5}$

Nevertheless, on account of the improvement of trade routes and the opening up of the country, there has in recent years been a great development both of the export and of the import trade of Manchuria. The principal exports are beans, bean-cake and bean-oil, produced mostly in the two southern provinces. Since the Chino-Japanese war of I894-5, Japan has bought practically all of Manchuria's bean crop, and her control of the export trade has been an important factor in the competition for the import trade. Recently, small shipments of beans and bean-oil have been made to Europe, and European firms in the Orient hope to increase these to offset Japan's advantage. ${ }^{6}$ In the northern section much grain is produced, which is for the most part consumed locally. The neighboring Russian-Siberian provinces, however, are dependent on this section for flour, grain and wheat, and as they develop by colonization, Northern Manchuria is certain to become more and more prosperous. Other leading items in the export trade are lumber, wild silk, and minerals. The lumber is cut under Japanese direction from the forests on the Yalu River. The wild silk industry is chiefly in southeastern Shenking. The vast mineral resources of the country are as yet comparatively undeveloped, although there is an average annual output of about $\$ 10,000,000$ in value from the gold, silver, copper, lead and iron mines, ${ }^{7}$ which are operated chiefly by the natives, and a large amount of coal is taken from the Japanese mines at Fushun, for use on the railroad and on steamers.

The import trade covers a wide range of articles, but there are certain great staples which have always formed the bulk of foreign shipments to this region. The most important of these are manufactures of cotton, which exceed in value all other foreign imports put together. Other items are kerosene, which is more

- See Monthly Consular Reports, No. 300, p. 93.

${ }^{\circ}$ In 1910, the total exports of bean products through Vladivostok, Dairen (Dalny), and Newchwang were: Beans, 920,266 tons (average price $\$ 14.50$ per ton); bean-cake, 516,160 tons; bean-oil, 40,124 tons. In 1909 , of $\$ 13,926,522$ total foreign exports at Dalny, bean products accounted for $\$ 12,884,043$. Exports to Japan were $\$ 8,302,533$.

TMonthly Consular Reports, No. 319, p. 69. 
and more widely used, lumber and tobacco. ${ }^{8}$ Flour, brought from the United States, once stood high in the list, but the great output of the mills in Northern Manchuria, which can grind the native wheat and sell it at a. price which no foreign flour can touch, has driven out the American product. At present, there is a promising but as yet undeveloped market for machinery of all kinds, especially for modern agricultural implements, which could be used to good advantage on the rather large farms of the region. These goods must be sold by native dealers in native stores, and the primary consideration which determines the popularity of an article is its cheapness. The better grades of Western manufactures find a market only among the small European element, while inferior goods, produced by cheap Oriental labor, and sold at a low price, are readily accepted. The Chinese are, however, good judges of quality, and are ready to pay better prices for superior goods if they can afford to, so that as the country develops there will undoubtedly be an increasing demand for first-class products.

Before the Russo-Japanese war, Manchuria imported more goods from the United States than from any other foreign country, and American imports at Newchwang between 1900 and 1904 amounted to about five million dollars annually. ${ }^{2}$ By far the most important commodities in this trade were cotton piece goods. In I9or, out of a total of $\$ 24,813,692$ native and foreign imports at Newchwang, $\$ 14,660,000$ represented cotton products, and of this about one-third was native Chinese textiles, one-third American piece goods, and the rest chiefly imports of yarn from India, Great Britain, Japan, and China. In Igoz, about thirty-five per cent of the total foreign imports at Newchwang came from the United States, and the greater part of this was cotton goods. In 1903, the total foreign imports were $\$ 13,3$ I4,0I2, and America's share was $\$ 5,562,255$, of which $\$ 4,873,960$ was cotton goods. These figures will suffice to show the position held by the United States in former years in regard to the most important import of Man-

\footnotetext{
8 Imports of tobacco, especially in the form of cigarettes, have increased immensely within the last few Jears, probably because of the curtailment of the supply of oplum.

- The figures given here are taken from the reports of United States Consuls, who secured them from the reports of the Native and Imperial Maritime Customs. As there has been almost no period since 1900 when there have been customs houses at all the ports of entry in Manchuria, such statistics must be considered rather as comparative than as exact.
} 
churia. ${ }^{10}$ The balance of the goods from America consisted chiefly of flour and kerosene, for each of which Manchuria offered a very important and continually expanding market.

Between I90I and I904, American commerce suffered considerably from the policy of Russia. This power had always exercised great influence in Manchuria, and she had, under various pretexts, finally established a measure of military control over the provinces. When she leased the Liaotung Peninsula in I898, and opened Dalny as a free port, she blocked the establishment of a Chinese customs house there until July, 1903. In 1901, as a result of the Boxer uprising, she occupied Newchwang. The same year, the Chinese Eastern Railway was opened to traffic, under her control. By discrimination in rates, and by preventing the collection of customs duties at Dalny, she attempted to divert to that port, where her own merchants were established, the trade formerly enjoyed by Newchwang, which was the base of the commerce carried on in Manchuria by other foreign countries. She also took measures to increase her own imports to the provinces. Fourteen steamers, subsidized to the amount of $\$ 309,000$ annually, ${ }^{11}$ were put in operation between European Russia and Vladivostok, Port Arthur and Dalny; and the Russo-Chinese Bank advanced large sums to Chinese merchants for the purchase of Russian goods. The same bank established a commercial branch to sell Russian oil and sugar. While other foreigners were still excluded from the interior, Russian subjects were to be found everywhere, building flour mills, meat packing establishments, and factories, opening mines, and selling Russian goods. Harbin, founded by the railroad company in 1896 , had a European population of 60,000 in 1904, and other Russian settlements increased rapidly in size.

This policy, however, was not entirely successful. Russian trade was stimulated, but it by no means drove out that of other nations. American cotton goods were imported in as great quantities as before, although the Russian government was exerting every effort to supplant them by the product of Russian mills, and the volume of American trade thus remained nearly the same. Nevertheless, because of the competition of Russian oil imported

10 In addition to the trade at Newchwang, there was also a certaln amount at Dalny, but no statistics are avallable for this because the customs house was not established there untll July, 1903.

21 U. S. Consular Reports, Vol. 73, p. 40. 
duty free at Dalny and carried at low rates on the railroad, the importation of American kerosene at Newchwang fell from 3,172,000 gallons in 1901, to 603,180 gallons in 1902; and American flour was almost driven from the market by the product of the Russian mills near Harbin. But these articles made up only a small part of the total trade. Russia's control of the railroad was not so great an advantage as it seemed, since the cost of transporting bulky freight on it was prohibitive, and thus it was not nearly so effective a means of distribution in the interior as were the junks on the Liao River at Newchwang. It had already become evident that Russia could not hope to monopolize the commerce of Manchuria without a more serious disregard of the "open door" than she had yet shown, when the war with Japan drove her out of the southern province and confined her influence to the sparsely settled North.

After the restoration of peace, American trade in Manchuria seemed to have a clear field. The subsidized Russian lines to Port Arthur and Dalny had disappeared, and the disorganized condition of the country had caused the flour mills in the North to close, so that American flour was in greater demand than ever before. American kerosene was in full control of the market, and American cotton goods seemed to have no important competitor, for over $\$ 9,000,000$ worth were imported into Manchuria in the year I905. The year after the war was one of unprecedented commercial activity. There followed, however, a period of depression. Foreign imports at Newchwang decreased by one-half in 1906, and decreased further in 1907 . This was due partly to the fact that Dalny was again without a customs house, but chiefly to the disastrous effects of the war on the interior. In 1908, a healthy revival set in, and the total imports increased steadily throughout Manchuria, especially with the opening of Antung, Mukden, and the important cities of the North. American trade, however, improved but little and soon began to fall off. In 1908 and I909, American consuls reported serious decreases in the amount of goods coming from the United States. In I9lo, our imports had fallen to a comparatively insignificant figure, and our trade in cotton goods, that is, the great bulk of all our trade, had largely passed into foreign hands. Our position of leadership in the Manchurian market was lost.

The nation which almost alone profited by this immense decline 
in American trade was Japan. In order to explain the great commercial advance of this power in Manchuria, it is necessary to sketch briefly the history of her systematic attempts to secure markets there for her products.

In the first place, Japan's geographical location gives her a decided advantage over Western nations competing with her for Manchurian trade. She is far nearer to China than any of her rivals, and is thus able to maintain regular, efficient, and cheap transportation with all of the ports in Shenking Province and with Vladivostok, where many goods are imported for use in the North. Her ownership of Korea makes it possible for her to send quick freight from Tokio to Harbin almost all the way by rail, over the Korean railroad and the Antung-Mukden line. She has a further advantage in her practical monopoly of the foreign export trade of the provinces, since a firm in China which does not do exporting as well as importing is exposed to serious financial difficulties from the variations in the rate of exchange.

Japan has not only made the most of her natural advantages in order to secure for herself the trade of Manchuria, but she has also taken extraordinary measures to assist her exporters. She had always enjoyed the greater part of the shipping and a fair share of the commerce of the provinces, but even before her war with Russia ended, it became evident that she intended to take advantage of her military occupation of the country to establish her trade still more firmly. ${ }^{12}$ Great quantities of goods were sent into the interior, and after the conclusion of peace, the transports which carried the army lome made their return trips profitable by bringing thousands of immigrants, who established themselves everywhere as farmers and merchants. While these merchants were doing an excellent business, foreign traders were rigorously excluded from the interior on the ground that military secrets were involved. ${ }^{13}$ It was asserted that the Japanese, supported by their troops, refused to pay the likin dues to which the goods of other nationalities were subjected, and further that they seized all of the desirable land in the cities which, according to treaty pro-

12 See the report of Special Agent Crist, in Monthly Consular Reports, No. 301.

12 The United States Foreign Relations for 1906 record numerous complaints from American merchants who were not allowed to go into the interior to look after their property and interests. 
visions, were soon to be opened to foreign trade. ${ }^{14}$ All concessions obtained or claimed by the Russians were taken over by the Japanese as a matter of course. In the summer of 1906, a great industrial and commercial exposition was held at Mukden to promote interest in Japanese products, and similar expositions were subsequently organized in other cities. Great quantities of Japanese goods were brought in duty-free at Dalny and over the Korean boundary, while other foreign goods were going through the customs house at Newchwang. ${ }^{15}$ These conditions were ameliorated with the gradual opening of the interior in 1906 and I907, and comparative equality of opportunity was again restored when customs houses at Dalny, Antung and Tatungkou, ports which had formerly been under Japanese control, were established on July I, 1907.

Equality of opportunity, however, could not be said to exist. Japan still retained control of the railroad, and, to a certain extent, of the financial system. By means of the railroad, she attempted to divert the trade of Newchwang to Dalny, or Dairen, as it is now officially called, by discriminatory rates, much as Russia had done. This policy has undoubtedly increased the commercial importance of the latter, although the former is still the chief port of entry. Japan also retained a certain amount of control over the currency of the provinces, which gave her banks an opportunity practically to regulate the rate of exchange. During the war with Russia, Manchuria had been flooded with Japanese "war notes," which were called in after the conclusion of peace and exchanged for notes issued by the Yokahama Specie Bank. These made up a large part of the currency, especially in Shenking, and were naturally a great aid in establishing a strong Japanese banking system.

When Manchuria was finally re-opened to foreign trade, Japanese products had secured a firm footing in the interior. Foreign merchants believed that this would be lost with the removal of the extraordinary advantages conferred by military occupation, but it soon became evident that even with the "open door" Japan was now a very dangerous competitor. The imperial government

14 In 1906, the Chinese government had great dificulty in finding a slte for the customs house at Antung, because the Japanese had taken possession of all of the land on the river front. See Foreign Relations for 1906, p. 221.

1s In 1907, it was estimated that Japanese imports to Manchuria in 1906 amounted to over $\$ 12,000,000$, of whlch less than $\$ 1,500,000$ paid duty at Newchwang. 
and the great business interests of the country united in a systematic attempt to get control of the import as well as the export trade of Japan's new "sphere of influence," as a part of their general scheme for national economic and industrial development. The liberal and progressive element, which was in complete political control after leading the nation to victory over Russia, extended the timehonored system of economic paternalism and did every thing in its power to promote the national industrial prosperity. The railways were already owned by the government, and the steamship lines were controlled through large subsidies. Manufactures were encouraged, and where an industry was injured by competition a trust was formed and placed under government supervision. For the surplus manufacturing products, and especially for those of the cotton mills, Manchuria offered an excellent outlet, if the United States could only be ousted from its commercial leadership there. The government and the manufacturers accordingly turned their attention to this task.

Cn May 30, 1906, the Jiji Shimpo announced that several large Japanese spinning and weaving companies had united in the Manchurian Export Gild, to advance their common interests and to export their goods under a common trade-mark. The Mitsui Bussan Kaisha, the leading commercial house of Japan, was to act as the general agent of this gild in Manchuria, and the Yokahama Specie Bank and other institutions were to loan money at $4^{\mathrm{T}} / 2$ per cent to merchants doing business there to enable them to purchase Japanese goods. The government guaranteed these loans, and also secured favorable rates on the railroads and on the subsidized steamship lines. In Manchuria itself, permanent representatives were appointed at all important towns, and travelling salesmen, well equipped with samples of goods and speaking Chinese fluently, were sent throughout the country. The consuls in the Eastern Provinces offered every possible assistance, and the manufacturers at home carefully followed their suggestions. In addition, commercial students, paid by the government, and under the direction of the nearest consul, studied the trade conditions in each locality, and their reports enabled the export houses to work more intelligently than was possible for those of other nations. In Japan itself, the mills steadily endeavored to improve the quality of their output, which was at first of a very inferior grade, and finally 
succeeded in making it nearly as good as, while far cheaper than, similar Western products.

This policy has met with remarkable success. In spite of the ingrained respect of Chinese merchants for long established trademarks, and in spite of the intense unpopularity. of Japanese goods caused by the dispute over the seizure of the steamer Tatsu Maru in 1908, and by the resentment among the Chinese at the Japanese policy in Manchuria itself, the imports of cotton goods from the Island Empire have now taken the leading place in the Manchurian market. ${ }^{16}$

The methods used to attain this position have been severely criticised. The counterfeiting of trade-marks, in particular, has caused much bitterness on the part of Western merchants, and strenuous efforts have been made to secure adequate protection against this practice. In 1904 , in accordance with her treaty obligations, China adopted a series of regulations for this purpose, which have proved entirely inadequate. In the following years, the United States made agreements with numerous powers for mutual protection by means of the consular courts in China, but Japan did not enter into such a compact. Trade-marks are of even more importance in China than in occidental countries, because the Chinese consumer always endeavors to secure the brand he has been accustomed to use, recognizing it by the trade-mark.

The decline of American trade in Manchuria is due primarily to Japanese competition, but the development of the native Chinese industries is a factor that should not be overlooked. The trade in native goods profited greatly from the steady decline in the value of silver which set in after the war, since this made the silver prices of foreign articles, which were manufactured by laborers paid in gold, much higher than those of goods made by laborers who still received their customary wages in silver. Chinese cotton goods, manufactured chiefly at Shanghai, have been gaining in popularity in Manchuria for at least ten years, since they are low-priced and are said to be of durable quality. The once large importations of American flour had already ceased before the war. After the war the mills in the North were unable to distribute their products in

16 In 1904, according to the Jiji shimpo (quoted in $\mathrm{U}$. S. Foreign Relations for 1906), the imports of sheetings and drills from Japan at Newchwang and Dalny were valued at only $\$ 18,206$, as compared with $\$ 5,347,900$ worth from the United States. The change effected by Japan's policy is striking. 
the South because of the destruction of part of the railroad, and great quantities of American flour were brought in. This importation practically ceased with the withdrawal of the army and the rebuilding of the railroad, and American flour is not now seen in Manchuria.

The competition of Japanese and native commerce was indeed formidable, but it could never have overcome the established reputation and popularity of American goods in so short a period if the exporters of the United States had made any intelligent effort to retain their hold on the Manchurian market. The one real fundamental cause of the decline in our trade has been the way in which it has been handled. In the first place, there has never been any regular direct steamer communication between our ports and those of Manchuria, although the volume of our trade, and the great saving in the cost of transshipment would make such a service very valuable. Our goods have generally gone to Shanghai, and have been imported into Manchuria from there largely by Chinese merchants or by firms of other nationalities, that is, the sale of our products has been in the hands of our commercial rivals. ${ }^{17}$ In the second place, American exporters seem to have paid no attention to the suggestions of consuls at Manchurian ports as to the peculiar requirements of the Manchurian market. Instead of sending samples of goods, which are an absolute necessity there, as a Chinaman will not buy wares which he has not seen, they have sent catalogues in English, which are entirely unintelligible to most of the merchants whom it is necessary to reach. Complaints are constantly heard of carelessness in packing and in sending shipments. Little effort, moreover, has been made to develop the great opportunities which Manchuria offers for the extension of trade into new lines, although the Consular Reports for the last decade have been full of suggestions regarding such possibilities. In short, the former American leadership in this trade has gone practically by default, because of the incompetence and carelessness of American exporters.

The present commercial position of the United States in Man-

17 In 1905, when our trade in Manchuria reached its highest point, there were three American business houses there, out of a total of 143 foreign establishments. (Monthly Consular Reports, No. 306, p. 90.) In 1907, American trade was largely bandled by the firm which was also agent for the Japanese Manchurian Export Gild, and by a German frm. (Monthly Consular Reports, No. 318, p. 102.) 
churia may be summarized as follows. Imports are practically confined to cotton goods, kerosene and tobacco, of which cotton goods are still the most important, although they have seriously decreased within the last three years. ${ }^{18}$ Our trade in kerosene and in tobacco, especially cigarettes, is still prosperous because these have been sold by aggressive and intelligent companies which have followed the same methods as are employed by Japanese firms in extending their trade. The Standard Oil Company is far ahead of its competitors from Sumatra, Russia and Borneo, and in I9Io over ten million gallons of American kerosene were imported out of a total of not quite fifteen million. The British-American Tobacco Company, which is practically an American concern, has been able to compete with no little success against the products of the Japanese government monopoly, largely because its factories are located at Shanghai, so that it has the advantages of direct transportation and of cheap Oriental labor. Each of the firms has an effective selling organization in the interior. With the exception of these two lines, however, our trade is at present either gone or rapidly disappearing.

How much chance will there be in the future for American trade to regain its former position in Manchuria? The answer to this question will depend largely on the respect shown by Japan for the "open door," the principle of equal opportunity for the commerce and industry of all nations. At the present time, it seems probable that the Mikado's government will continue to respect this principle, both from necessity and from regard for its own interests. In the first place, it is not likely that Japan will be able to acquire more extensive political control over the Eastern Provinces than she already enjoys. Japanese immigration to Manchuria has not been large, because, as a close student of Chinese conditions has pointed out, her immigrants have never been able to compete with the native stock either as merchants or as farmers. ${ }^{19}$ The country

18 In 1905, the United States practically monopolized the trade in plece goods. The number of pieces of drills, jeans, and sheetings imported into Manchuria during the last two years was, howerer, as follows:

\begin{tabular}{|c|c|c|c|c|c|c|c|}
\hline & & \multicolumn{2}{|c|}{ Drills } & \multicolumn{2}{|c|}{ Jeans } & \multicolumn{2}{|c|}{ Sheetings } \\
\hline & & 1009 & 1910 & 1909 & 1910 & 1909 & 1910 \\
\hline Amerlcan & $\ldots \ldots \ldots$ & 319,428 & 186,698 & 98,111 & 3,968 & 706,735 & 378.121 \\
\hline Japanese & $\ldots \ldots$ & 114,814 & 252,342 & $\ldots$ & $\ldots \ldots$ & 261.743 & 694,574 \\
\hline British. & $\ldots \ldots \ldots \ldots$ & 12,359 & 6.750 & 278,258 & 323,246 & 69,953 & 15,231 \\
\hline
\end{tabular}

$19 \mathrm{~J}$. W. Jenks in the Outlook, March 11, 1911. 
will remain distinctly Chinese, and any outside control must take the form of domination rather than of absorption. Moreover, any attempt seriously to interfere with foreign trade would bring on the active hostility of all the other powers which are important in Eastern affairs, and especially that of the United States and Great Britain, whose friendship Japan could not afford to lose. These powers, even if they did not consider their own commerce, would not tolerate any interference with the tariff or with the trade on which the amount of the duties levied depends, because of their interest in the Chinese debt, which is secured by the customs revenues. China herself, also, would be an insuperable obstacle to Japanese political control in Manchuria. The concessions now held by Japan for the most part revert to China at the end of varying periods, and in view of the remarkable national development of the Celestial Empire during the last few years, it seems probable that she will be able to insist on and secure her rights when these periods expire.

Moreover, even if Japan were able to shut out the commerce of other nations from Manchuria, it would not be to her interest to do so. Her geographical advantages alone enable her to control a large share of the trade in commodities which she produces, and the increased prosperity which the general commercial development of the country will carry with it must, in the long run, be favorable to Japanese exporters. The few American merchants who have shown sufficient interest in Manchuria to send their goods to the commercial expositions, held by the Japanese at all of the important distributing points, report that they were treated with courtesy and that their goods were well exhibited at very reasonable charges. It must also be considered that Japanese capital can never suffice for the development of the great concessions of which Japan took possession after the war. For the sake of these, foreign capital must be attracted to the country, and this can only be done by the frank acceptance of the "open door" policy.

The actions of Japan which have recently given rise to the numerous accusations that she intended to do away with the open door in Manchuria, may generally be ascribed, not so much to a desire to injure foreign commercial interests as to a determination to maintain the value of her own concessions. For instance, the opposition to China's attempts to build the Hsinmintun-Fakumen 
railroad into the interior has arisen from a fear that this line would compete with the Japanese-owned Southern Manchurian line and would also draw trade away from the Japanese port of Dairen, or Dalny. The indirect attempts to injure the commerce of Newchwang are due to a desire to make Dairen more prosperous. Whatever the secondary effects of Japan's policy may be, she seems to have no intention, at present, of trying to stifle foreign enterprise, and where foreign trade is being driven out, it is not by a system of exclusion but by strenuous competition.

It should be remembered, moreover, that Japan's sphere of influence covers only about one-third of Manchuria. The twothirds still under the influence of Russia is, it is true, less thickly populated and less important commercially, but a large immigration is constantly increasing its value as a market, and it is said to be fully as fertile as the southern region. Without some radical violation of the open door principle, however, which will be as difficult for her as for Japan, Russia's commercial rivalry will not be formidable here. The cost of bringing bulky goods from Europe on the railroad is prohibitive, and goods brought by sea must come through Vladivostok, which is closed by ice part of the year, or through the southern ports and from there into the interior on the Japanese railway. In either case, the sea route from European Russia is longer and more expensive than that from the United States. Japanese trade has already secured a foothold north of Changchun, and no doubt properly handled American trade could do the same.

It seems probable, then, that in the future Manchuria will be open to the commerce of all nations on equal terms. There is no reason why American exporters, by adopting a new policy, should not be able to increase greatly the sale of our products there, if they will only make an effort to do so. American banks should be established in the principal Manchurian trade centers and Manchurian products should be brought direct to the United States. A considerable amount of Manchurian bean-oil is now used here, but it is imported from Europe, after being expressed there. ${ }^{20}$ In addition, an efficient method should be adopted for selling goods after

\footnotetext{
Dnder the Payne-Aldrich tariff the duty on beans is 45 cents per bushel of 60 pounds, which is nearly 100 per cent in the case of Manchurian beans. This naturally would prevent their importation into this country. The duty on expressed olls is only 25 per cent.
} 
they have reached the Eastern Provinces. In dealing with Chinese merchants, personal relations by means of local agents are necessary, and samples of wares should be used rather than catalogues written in English. If a really effective policy were adopted, soon we should again be sending large quantities of goods to Manchuria. Even though our cotton products were unable to compete with the government-aided output of Japanese mills, we could still sell machinery of all kinds, and stoves, shoes, condensed milk, and countless other manufactures for which a demand exists or will soon exist in the Manchurian market. We could thus always have a fair share in this trade, whereas at present the amount of American goods imported grows smaller each year. It would be a great misfortune for American industry if we should lose entirely our part in this already great and rapidly growing trade; and if this is to be avoided, an active policy of developing our Manchurian commerce must be inaugurated at once. 